DOI: $10.6060 / \mathrm{mhc} 2012.121199 \mathrm{~b}$

\title{
Trimer Porphyrin Star ${ }^{\star}$
}

\author{
Yulia P. Yaschuk, Vladimir S. Tyurin and Irina P. Beletskaya ${ }^{\circledR}$ \\ ${ }^{\star}$ This star is dedicated to Aslan Yu. Tsivadze on the occasion of his $70^{\text {th }}$ anniversary \\ A.N. Frumkin Institute of Physical Chemistry and Electrochemistry of Russian Academy of Sciences, 119071 Moscow, \\ Russian Federation \\ @Corresponding author E-mail: beletska@org.chem.msu.ru
}

\begin{abstract}
A novel tripod star-shaped porphyrin trimer has been synthesized using “click” methodology (Huisgen's 1,3-diploar cycloaddition reaction) from zinc(II) 5-(4-azidophenyl)-10,15,20-trimesitylporphyrin and 1,3,5-triethynylbenzene. The porphyrin tripod star was shown to exhibit coordination with DABCO and Bipy forming cofacial dimer aggregates and characterized by MS, NMR and UV-vis spectroscopy.
\end{abstract}

Keywords: Porphyrin trimer, click chemistry, triazole bridge, star shaped molecule.

\section{ЗвезАообразный тример порфирина}

\author{
Ю. П. Ящук, В. С. Тюрин, И. П. Белецкая ${ }^{\circledR}$ \\ Посвящается Аслану Юсуповичу Циваgзе по случаю его 70-летнего юбилея
}

Институт физической химии и электрохимии им. А.Н. Фрумкина РАН, 119071 Москва, Россия

${ }^{\circledR}$ E-mail: beletska@org.chem.msu.ru

\begin{abstract}
Используя клик-методологию (реакияия 1,3-диполярного ичилоприсоединения Хьюсгена) из 5-(4-азидофенил)10,15,20-тримезитилпорфиринатоцинка and 1,3,5-триэтинилбензола синтезирован новый звездообразный тример порфирина, который охарактеризован с помощью масс-спектрометрии, ЭСП и ЯМР спектроскопии. Показано, что полученная порфириновая трехлучевая звезда способна координировать DАВСО и Віру, образуя кофачиильные димерные агрегатыл.
\end{abstract}

Ключевые слова: Тример порфирина, клик-методология, триазольный мостик, звездообразная молекула.

\section{Introduction}

Design of star-shaped molecules with porphyrin arms is not only interesting academic objective of construction of new large molecules with attractive aesthetic architecture but it is suitable for the creation of new materials formed as a result of self-organization or coordination assembly. The combination of such chromophores in an ensemble allows one to expect new interesting photophysical properties. ${ }^{[1]}$ There have been synthesized several porphyrin brunched stars with different linkers and cores. ${ }^{[2-6]}$ The porphyrin cored stars were used as light-harvesting antennas..$^{[7,8]}$ The nature of the bridge linking porphyrin arms to the core exerts a strong influence on properties of the star. Both electronic nature of linkers and the spatial organization of chromophores on the nanoscale level are the key factors determining an efficiency of antennas functionality. ${ }^{[9,10]}$ To the present time there has not been synthesized a porphyrin star with 1,2,3-triazole arm linkers. Triazole heterocycle represents non-interfering linker simply formed via so called "click" reaction - Huisgen's 1,3diploar cycloaddition allowing for connection of independent molecular species together with accompanying interesting conformational and supramolecular features. ${ }^{[11-13]}$ At present time only a few porphyrin dimers with 1,2,3-triazole bridge 
have been synthesized ${ }^{[14-16]}$ thus the construction of "click"connected multiporphyrin systems and particularly "click"built porphyrin star is of special interest.

\section{Experimental}

${ }^{1} \mathrm{H}(600 \mathrm{MHz})$ and ${ }^{13} \mathrm{C}(125 \mathrm{MHz})$ NMR spectra were recorded on Bruker Avance 600 spectrometers in IPCE RAS at room temperature and referenced to the residual protons of solvent $\left(\mathrm{CDCl}_{3}-\delta 7.28 \mathrm{ppm}\right.$, methanol- $\left.d_{6}-\delta 4.84 \mathrm{ppm}, 3.31 \mathrm{ppm}\right)$. MALDI-TOF mass spectra were recorded on an Ultraflex MALDI TOF Bruker Daltonics spectrometer in IPCE RAS with positiveion mode, voltage $20 \mathrm{mV}$ ), with dithranol matrix. UV-Vis spectra were recorded on spectrometer Cary-100 Varian. Semi-empirical AM1 calculations were performed by using HyperChem 6.03 program. ${ }^{[17]}$ Dioxane was distilled and dried over sodium under argon. $\mathrm{CH}_{2} \mathrm{Cl}_{2}$ was distilled over $\mathrm{CaH}_{2}, \mathrm{CHCl}_{3}$ was distilled over $\mathrm{P}_{2} \mathrm{O}_{5}$ and was freed from acids by stirring over dry $\mathrm{K}_{2} \mathrm{CO}_{3}$. All reactions were performed under argon atmosphere and monitored by TLC Macherey-Nagel Alugram SIL G/UV ${ }_{254}$ silica gel 60 $\mathrm{UV}_{254}$ with eluent $\mathrm{CH}_{2} \mathrm{Cl}_{2}-\mathrm{MeOH}$. Column chromatography was performed on silica gel Macherey-Nagel 60 0.04-0.063 (230-400 mesh). All other chemicals used for the synthesis were reagent grade unless otherwise specified. 1,3,5-Triethynylbenzene, 5-(4tert-butylphenyl)dipyrromethane, ${ }^{[18]} \quad 5$-(4-nitrophenyl)-dipyrromethane ${ }^{[19]}$ and 5-mesityldipyrromethane ${ }^{[20]}$ were synthesized as described previously and purified by column chromatography on silica; 1,3,5-triethynylbenzene was obtained from 1,3,5tribrombenzene following the described procedure. ${ }^{[21]}$

5,15-Dimesityl-10-(4-tert-butylphenyl)-20-(4-nitrophenyl)porphyrin (1); 5,15-Dimesityl-10-(4-tert-butylphenyl)-20-(4-aminophenyl)-porphyrin (2). 5-Mesityldipyrromethane (0.66 g, 2.5 $\mathrm{mmol})$ was mixed with $p$-nitrobenzaldehyde $(0.189 \mathrm{~g}, 1.25 \mathrm{mmol})$ and 4-tert-butylbenzaldehyde $(0.2 \mathrm{ml}, 1.25 \mathrm{mmol})$ in $\mathrm{CH}_{2} \mathrm{Cl}_{2}(250$ $\mathrm{ml})$ then TFA $(0.34 \mathrm{ml}, 4.45 \mathrm{mmol})$ was added and the mixture was strirred for $80 \mathrm{~min}$ followed by the oxidation with DDQ by described procedure. ${ }^{[22]}$ After that the solvent was removed under vacuum and the residual black solid was poured onto a pad of silica and eluted with $\mathrm{CH}_{2} \mathrm{Cl}_{2}$. Evaporation of the solvent under vacuum gave a brown residue of $\mathbf{1}$ which was used in the next step without products separation. Reduction of nitro groups was performed as follows: brown solid was dissolved in $1: 2 \mathrm{CHCl}_{3} / \mathrm{HOAc}(30 \mathrm{ml})$ and a solution of $\mathrm{SnCl}_{2} \cdot 2 \mathrm{H}_{2} \mathrm{O}(903.6 \mathrm{mg}, 4 \mathrm{mmol})$ in concentrated $\mathrm{HCl}$ $(10 \mathrm{ml})$ was added. The mixture was vigorously stirred in a preheated oil bath $\left(65-70{ }^{\circ} \mathrm{C}\right)$ for $30 \mathrm{~min}$, refluxed for $7 \mathrm{~h}$, and then neutralized with ammonia solution $(25 \%)$ to $\mathrm{pH} 8-9$. Chloroform $(100 \mathrm{ml})$ was added, and the mixture was stirred for $1 \mathrm{~h}$. The organic phase was separated, and the water phase was extracted with $\mathrm{CHCl}_{3}(2 \times 100$ $\mathrm{ml})$. The combined organic layers were washed once with dilute ammonia solution, three times with water, and then concentrated to dryness. Chromatography separation: elution with $\mathrm{CH}_{2} \mathrm{Cl}_{2}: \mathrm{PE}=2: 1$ gave first purple layer of 5,15,10,20-tetramesitylporphyrin (as a byproduct); then the product 2 was eluted in a second fraction which after solvent evaporation gave $199 \mathrm{mg}$ of the purple solid $\mathbf{2}$ with overall $22 \%$ yield after two steps. ${ }^{1} \mathrm{H} \mathrm{NMR}\left(\mathrm{CDCl}_{3}, 298 \mathrm{~K}\right) \delta_{\mathrm{H}} \mathrm{ppm}$ : $-2.55(2 \mathrm{H}, \mathrm{s}), 1.63(9 \mathrm{H}, \mathrm{s}), 1.85(12 \mathrm{H}, \mathrm{s}), 2.66(6 \mathrm{H}, \mathrm{s}), 7.08(2 \mathrm{H}$, d $J=8.2 \mathrm{~Hz}) 7.31(4 \mathrm{H}, \mathrm{s}), 7.77(2 \mathrm{H}, \mathrm{d} J=8.2 \mathrm{~Hz}), 8.03(2 \mathrm{H}, \mathrm{d} J=$ $8.2 \mathrm{~Hz}), 8.17(2 \mathrm{H}, \mathrm{d} J=8.2 \mathrm{~Hz}), 8.70(4 \mathrm{H}, \mathrm{d} J=4.6 \mathrm{~Hz}), 8.86(2 \mathrm{H}$, $\mathrm{d} J=4.6 \mathrm{~Hz}), 8.91(2 \mathrm{H}, \mathrm{d} J=4.6 \mathrm{~Hz})$.

Zinc(II) 5,15-dimesityl-10-(4-tert-butylphenyl)-20-(4-azidophenyl)porphyrin (3). Porphyrin $2(0.160 \mathrm{~g}, 0.2 \mathrm{mmol})$ was dissolved in $3.2 \mathrm{ml}$ of TFA and cooled to $0{ }^{\circ} \mathrm{C}$ in the ice bath. Sodium nitrite $(0.029 \mathrm{~g}, 0.41 \mathrm{mmol})$ was dissolved in $0.8 \mathrm{ml}$ of water and added to the mixture, which was then stirred for $30 \mathrm{~min}$ at $0{ }^{\circ} \mathrm{C}$. Sodium azide $(0.039 \mathrm{~g}, 0.6 \mathrm{mmol})$ was dissolved in $0.8 \mathrm{ml}$ of water and added to the reaction mixture. After the reaction was stirred on ice for $1 \mathrm{~h}$, cold water was added to the flask. The crude mixture was extracted with $\mathrm{CH}_{2} \mathrm{Cl}_{2}$, and the green organic layer was washed with water until it turned purple. The organic phase was dried over $\mathrm{Na}_{2} \mathrm{SO}_{4}$, filtered, and concentrated under vacuum to about $150 \mathrm{ml}$. Zinc acetate ( $2 \mathrm{~g}, 9.12 \mathrm{mmol}$ ) was dissolved in $\sim 25 \mathrm{ml}$ of $\mathrm{MeOH}$ and added to the porphyrin solution. The reaction was heated at reflux for $1 \mathrm{~h}$, and the crude mixture was washed with water three times. The organic layer was dried over $\mathrm{Na}_{2} \mathrm{SO}_{4}$ and filtered. Flash column chromatography with silica gel was used to purify the crude material using $\mathrm{CH}_{2} \mathrm{Cl}_{2}$ as an eluent, and the desired product was eluted with the solvent front to give after evaporation $128 \mathrm{mg}(80$ \%) of 3. ${ }^{1} \mathrm{H} \mathrm{NMR}\left(\mathrm{CDCl}_{3}, 298 \mathrm{~K}\right) \delta_{\mathrm{H}} \mathrm{ppm}: 1.63(9 \mathrm{H}, \mathrm{s}), 1.85(12 \mathrm{H}$, s), $2.66(6 \mathrm{H}, \mathrm{s}), 7.31(4 \mathrm{H}, \mathrm{s}), 7.40(2 \mathrm{H}, \mathrm{d} J=8.1 \mathrm{~Hz}), 7.77(2 \mathrm{H}, \mathrm{d}$ $J=8.1 \mathrm{~Hz}), 8.17(2 \mathrm{H}, \mathrm{d} J=8.1 \mathrm{~Hz}), 8.23(2 \mathrm{H}, \mathrm{d} J=8.1 \mathrm{~Hz}), 8.80$ $(4 \mathrm{H}, \mathrm{m}), 8.88(2 \mathrm{H}, \mathrm{d} J=4.6 \mathrm{~Hz}), 8.96(4 \mathrm{H}, \mathrm{d} J=4.6 \mathrm{~Hz}) . \mathrm{UV}-$ vis $\left(\mathrm{CH}_{2} \mathrm{Cl}_{2}\right) \lambda_{\text {max }} \mathrm{nm}(\lg \varepsilon)$ : 421 (5.40), 550 (4.07), 589 (3.62). MS (MALDI-TOF) calculated for $\left[\mathrm{C}_{54} \mathrm{H}_{49} \mathrm{~N}_{5} \mathrm{Zn}\right]^{+}$831.3279; observed $m / z 831.31\left[\mathrm{M}-\mathrm{N}_{2}\right]^{+}$.

Star porphyrin trimer 4 . A small round-bottomed flask was charged with 3 equiv $(0.057 \mathrm{~g}, 0.066 \mathrm{mmol})$ of azidoporphyrin $\mathbf{3}$, 1 equiv $(0.003 \mathrm{~g}, 0.022 \mathrm{mmol})$ of 1,3,5-triethynylbenzene, then 5 equiv $(0.022 \mathrm{~g}, 0.111 \mathrm{mmol})$ of $\mathrm{CuSO}_{4} \cdot 5 \mathrm{H}_{2} \mathrm{O}$ (stock aqueous solution $33 \mathrm{~g} / \mathrm{l}), 10$ equiv $(0.44 \mathrm{~g}, 0.222 \mathrm{mmol})$ of sodium ascorbate in DMF (saturated solution). The reaction mixture was stirred at $90{ }^{\circ} \mathrm{C}$ for $10 \mathrm{~h}$. The progress of reaction was monitored by TLC. After cooling, the product was extracted with $\mathrm{CH}_{2} \mathrm{Cl}_{2}$. The resulting organic layer was dried with $\mathrm{Na}_{2} \mathrm{SO}_{4}$ and evaporated to dryness, a coloured solid was obtained. Product was isolated via column chromatography: unreacted starting materials were eluted as the first fraction in $\mathrm{CH}_{2} \mathrm{Cl}_{2}: \mathrm{PE} 1: 1$, target product was eluted with $1 \% \mathrm{MeOH}$ in $\mathrm{CH}_{2} \mathrm{Cl}_{2}$ as a second fraction to give after evaporation $18 \mathrm{mg}$ (30\%) of $4 .{ }^{1} \mathrm{H} \mathrm{NMR}\left(\mathrm{CDCl}_{3}, 298 \mathrm{~K}\right)$ $\delta_{\mathrm{H}}$ ppm: $1.64(27 \mathrm{H}, \mathrm{s}, t-\mathrm{Bu}), 1.87\left(18 \mathrm{H}, \mathrm{s}, o-\mathrm{CH}_{3}\right), 1.88(18 \mathrm{H}, \mathrm{s}$, $\left.o-\mathrm{CH}_{3}\right), 2.67\left(18 \mathrm{H}, \mathrm{s}, p-\mathrm{CH}_{3}\right), 7.32(12 \mathrm{H}, \mathrm{s}, m-\mathrm{H}$ mesityl), 7.78 $\left(6 \mathrm{H}, \mathrm{d} J=7.7 \mathrm{~Hz}, m-\mathrm{H} t-\mathrm{BuC}_{6} H_{4}\right), 8.19(6 \mathrm{H}, \mathrm{d} J=7.7 \mathrm{~Hz}, o-\mathrm{H}$ $t$ - $\left.\mathrm{BuC}_{6} H_{4}\right), 8.32\left(6 \mathrm{H}, \mathrm{m}, o-\mathrm{H}\right.$ triazolyl $\left.\mathrm{C}_{6} H_{4}\right), 8.48-8.54(6 \mathrm{H}, \mathrm{m}$, $m$-H triazolyl $\left.\mathrm{C}_{6} \mathrm{H}_{4}\right), 8.73\left(3 \mathrm{H}\right.$, s, triazole), $8.93\left(3 \mathrm{H}\right.$, br s, $\left.\mathrm{C}_{6} \mathrm{H}_{3}\right)$, 8.81-8.98 $(24 \mathrm{H}, \mathrm{m}, \beta-\mathrm{H}) .{ }^{13} \mathrm{C}\left(\mathrm{CDCl}_{3}, 298 \mathrm{~K}\right) \delta_{\mathrm{C}} \mathrm{ppm}: 161.17$, $149.97,149.89,149.73,149.50,148.01,144.25,139.24,139.17$, $139.09,137.37,137.34,136.31,135.58,131.94,131.58,131.16$, $131.07,130.87,127.63,118.86,118.74,118.56,117.77,107.73$, 102.41, 99.49, 43.80, 23.04, 21.74, 21.47. UV-vis $\left(\mathrm{CH}_{2} \mathrm{Cl}_{2}\right) \lambda_{\max }$ nm (lg $\varepsilon$ ): 421 (5.96), 550 (4.69), 587 (3.87). MS (MALDI-TOF) calculated for $\left[\mathrm{C}_{174} \mathrm{H}_{148} \mathrm{~N}_{15} \mathrm{Zn}_{3}\right] 2641.9919$, observed $\mathrm{m} / \mathrm{z} 2641.89$ $\left[\mathrm{M}+\mathrm{H}-3 \mathrm{~N}_{2}\right]^{+}$.

\section{Results and Discussion}

In the present work we have for the first time performed the synthesis of a porphyrin trimer using the "click" chemistry approach. The 1,3,5-triethynylbenzene has been linked to the three azido functionalized porphyrin molecules. The azide building block is nonsymmetrically tetrameso substituted porphyrin of trans-ABC - -type. Its design is based on the following notions: the presence of tert-butyl group serves to improve porphyrin solubility and mesityl substituents suppress scrambling processes in the course of synthesis, ${ }^{[22]}$ both bulky groups prevent cofacial aggregation as well contribute to solubility. The synthesis of such porphyrin was accomplishedviastatisticalmixedaldehyde-dipyrrylmethane MacDonald [2+2] condensation (Scheme 1). Along with the target compounds formation of several more symmetric side products usually occurs. However, under optimized conditions the reaction of 5-mesityldipyrromethane with 4-nitrobenzaldehyde and 4-tert-butylbenzaldehyde furnished the novel nitrophenyl functionalized porphyrin 1 in $28 \%$ 
yield which is quite high for such type of the reaction. Earlier reported meso-substituted porphyrins bearing single nitro- or acetamidophenyl group as azide precursors were obtained in considerably lower yields in a range $10-18 \% .^{[14,23-26]} 5$-(4-tertButylphenyl)dipyrromethane, ${ }^{[18]}$ 5-(4-nitrophenyl)-dipyrromethane $^{[19]}$ and 5-mesityldipyrromethane ${ }^{[20]}$ were easily obtained in high yields by the published procedures. The reduction of nitro group was carried out in $\mathrm{CHCl}_{3} / \mathrm{AcOH}$ by $\mathrm{SnCl}_{2} / \mathrm{HCl}$ to give the 4-aminophenyl substituted porphyrin 2 in $80 \%$ yield. Diazotization of $\mathbf{2}$ with TFA/ $\mathrm{NaNO}_{2}$, followed by one-pot substitution reaction with $\mathrm{NaN}_{3}$ furnished mesobis(4-azidophenyl)porphyrin which was further converted by reaction with zinc acetate to the desired zinc porphyrin 3 with $78 \%$ yield over two stages (Scheme 1).

Finally the three-arm porphyrin star 4 was assembled by click reaction of the azidoporphyrin 3 with 1,3,5triethynylbenzene (Scheme 2). We investigated the various reported reaction conditions for the $\mathrm{Cu}^{\mathrm{I}}$-catalyzed Huisgen's 1,3-dipolar cycloaddition (click reaction), giving a range of yields with porphyrins, ${ }^{[27]}$ in order to find the optimized procedure. Most of methods led to traces of products. The optimal procedure was found to include the following: copper sulphate with sodium ascorbate as a catalyst with reagents dissolved in aqueous DMF were heated at $90{ }^{\circ} \mathrm{C}$ for $10 \mathrm{~h}$. Advantages of the procedure include the cheap and readily accessible catalyst, relatively simple work-up allowing easy isolation of the product. The compound $\mathbf{4}$ was obtained in moderate $30 \%$ yield after column chromatography which is an effect of the three sequential "clicks" proceeded. During mass-spectral analysis, the fragmentation of triazole compounds readily occurs with a loss of nitrogen molecules. Thus MALDI-TOF spectra of $\mathbf{4}$ show the following isotopic ion clusters: molecular ion of the trimer/dimer and ions resulted from the loss of $\mathrm{N}_{2}$ molecules from triazole bridges. The geometry optimization performed with semi-empirical AM1 method produced the structural view of the molecule (Figure 1). It looks like a propeller with porphyrin planes as propeller blades being near orthogonal to the central benzene ring. The ${ }^{1} \mathrm{H}$ NMR resonance signals were assigned by comparison with the spectra of starting porphyrin monomers, and the reported data for porphyrin-triazole compounds. ${ }^{[16,23]}$ ${ }^{1} \mathrm{H}$ NMR spectra show the typical singlet of the 1,2,3-triazole unit at $\delta 8.73 \mathrm{ppm}$.

The data of UV-Visible absorption spectra (Figure 2) of the synthesized compounds (star porphyrin 4 , the starting porphyrin building block 3 and the mixture of 4 with exo-bidentate ligand diazabicyclo[2.2.2] octane (DABCO)) are presented in the Table 1. The spectra contain the intense near-UV Soret band at $421 \mathrm{~nm}$ and the weaker two visible $Q$ bands: one at $587 \mathrm{~nm}$ and second more intense band at $550 \mathrm{~nm}$. The positions of the bands of trimer product $\mathbf{4}$ and starting monomer $\mathbf{3}$ are almost

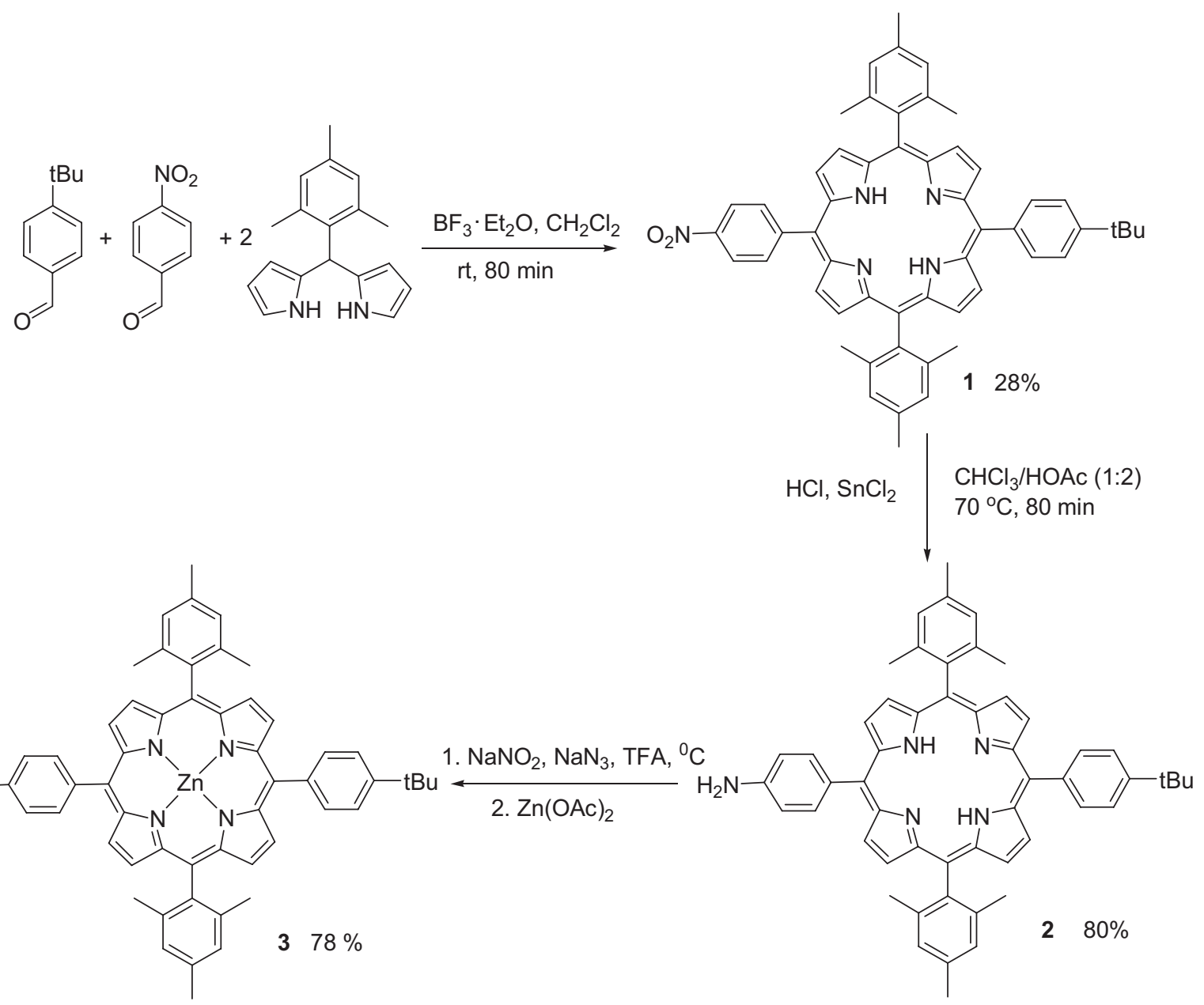

Scheme 1. Azidoporphyrin synthesis procedure. 
<smiles>C#Cc1cc(C#C)cc(C#C)c1</smiles>

Scheme 2. Synthesis of the star porphyrin trimer

coincide with each other indicating the weak intramolecular interporphyrin communication but the intensity of absorption has considerably increased. The Soret band of $\mathbf{4}$ is sharp and doesn't display broadening typical for closely linked multiporphyrins arising from splitting of energy levels which is a consequence of point-dipole excitation coupling ${ }^{[28,29]}$ and reported as characteristic for planar meso-meso linked multiporphyrins. ${ }^{[30]}$ Relatively large interchromophore distance and nonplanar positions of porphyrin units, which can be seen at the molecular model of $\mathbf{4}$ diminish that electronic communication as well as perpendicular turned benzene rings break conjugation

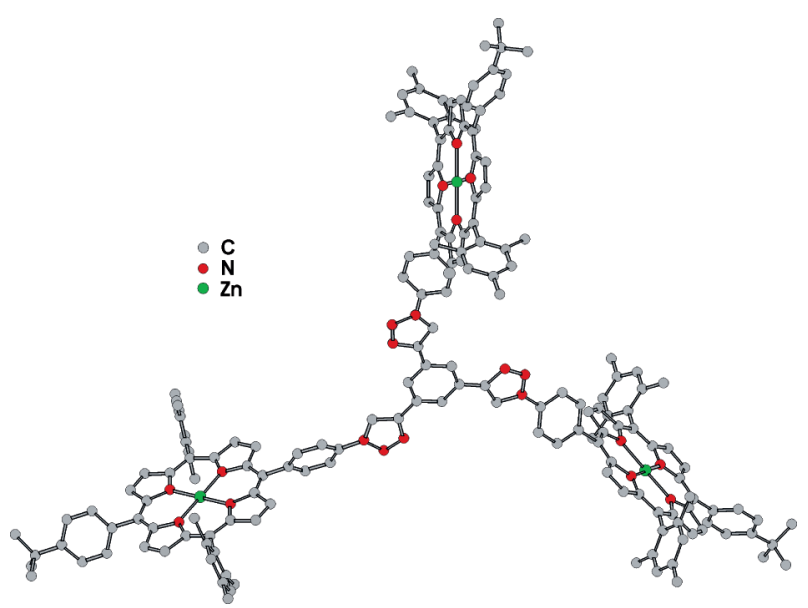

Figure 1. The geometry of 4 optimized by AM1. between neighbouring $\pi$-electronic systems (Figure 1). To probe the supramolecular assembling ability of the porphyrin star two nitrogen contained exobidentate ligands 4,4'-bipyridine (Bipy) and 1,4-diazabicyclo[2.2.2]octane

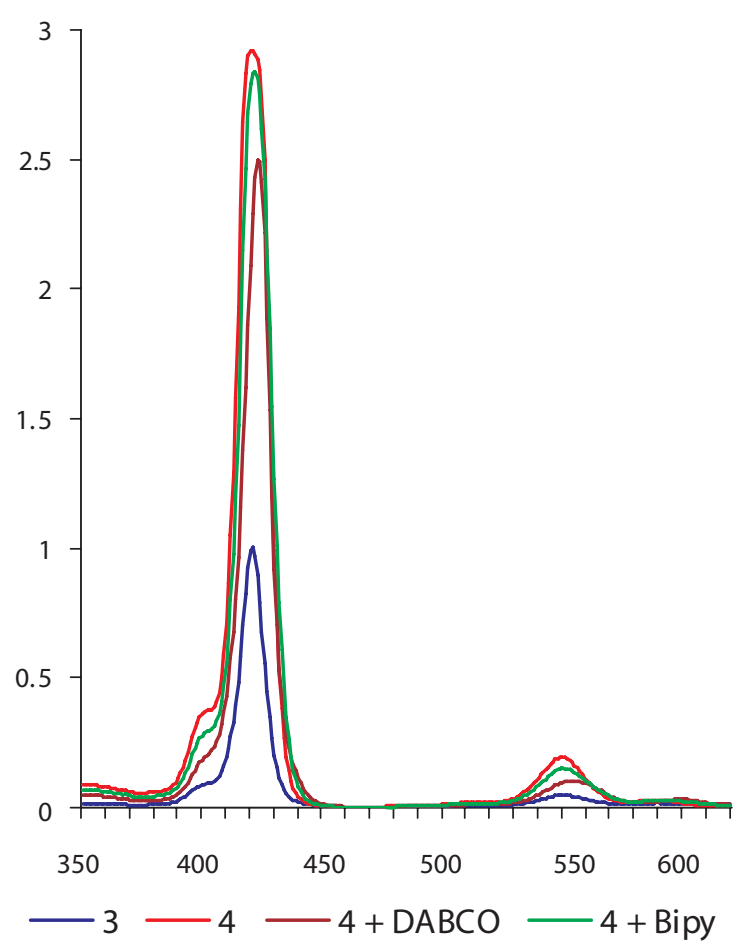

Figure 2. UV-vis absorption spectra of the porphyrins 3, 4, 4+DABCO, and 4+Bipy. 
(DABCO) were added. Both ligands notably decrease the extinction coefficients of all the bands of $\mathbf{4}$ proportionally to their donor ability. DABCO - zinc porphyrin coordination led to the slight bathochromic shift of the Soret band and the $Q$ bands. Weaker ligand Bipy gave a subtle change of the spectra. Normally the axial coordination of nitrogen ligands to zinc porphyrins causes much larger bathochromic shift of the Soret band. The observed shifts possibly reflect concurrent influence of ligand coordination increasing electron density in the tetrapyrrolic macrocycle resulting to bathochromic shift and cofacial interaction of the electronic systems of two porphyrin macrocycles at porphyrin star dimer which can be formed via DABCO coordination bridge (Scheme 3). Such cofacial arrangement of porphyrin electronic systems shifts Soret band to higher energy. The real equilibrium in the system of the molecule with three coordination sites with bidentate ligand is quite complex, so the Scheme 3 represents the simplified version of the reaction suggested on the basis of the reported analogous porphyrin coordination dimers with DABCO. [31] The detailed photophysical studies of supramolecular coordination assemblies of the porphyrin star are in progress.

Table 1. Absorption data of star-shaped trimer along with the $\mathrm{ZnP}$ monomer recorded in dichloromethane. Absorption characteristics were measured at r.t., samples concentration $4 \cdot 10^{-6} \mathrm{M}$.

\begin{tabular}{ccc}
\hline Compound & $\begin{array}{c}\text { Soret band } \lambda_{\text {max }} \\
(\lg \varepsilon), \mathrm{nm}\end{array}$ & $\begin{array}{c}Q \text { bands } \lambda_{\text {max }} \\
(\lg \varepsilon), \mathrm{nm}\end{array}$ \\
\hline $\mathbf{3}$ & $421(5.40)$ & $550(4.07), 589(3.62)$ \\
$\mathbf{4}$ & $421(5.96)$ & $550(4.69), 587(3.87)$ \\
$\mathbf{4}+$ DABCO & $423(5.80)$ & $553(4.40), 600(3.90)$ \\
4 + Bipy & $422(5.85)$ & $550(4.58), 591(3.82)$ \\
\hline
\end{tabular}
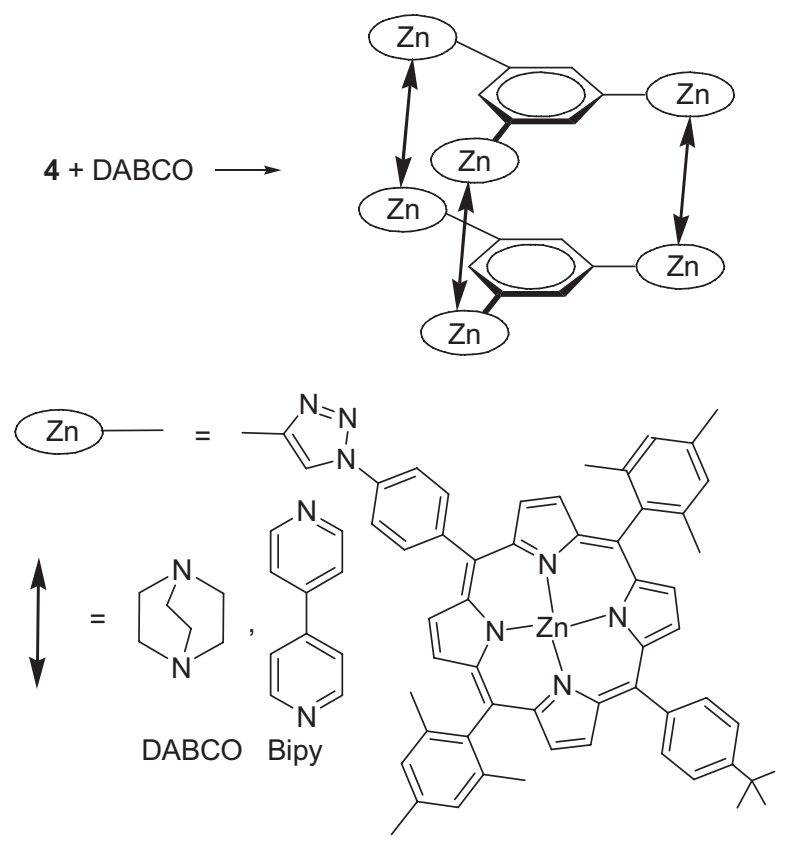

Scheme 3. The suggested coordination of $\mathbf{4}$ with $\mathrm{DABCO}$ and Bipy.

\section{Conclusions}

Synthesis of the novel 1,3,5-benzene-centered 1,2,3triazole-linked porphyrin star trimer was achieved based on "click" chemistry approach. Optimized conditions of the nonsymmetrical porphyrin synthesis gave high yield of the azidoporphyrin building block. Copper catalyzed 1,3-dipolar cycloaddition connecting three azidoporphyrin molecules with triethynylbenzene to produce porphyrin star trimer. Static absorption properties revealed absence of inter-porphyrin electronic communication. The interaction of the star with DABCO and Bipy possibly led to the double star formed by axial coordination of ligand with zinc centers.

Acknowledgements. This work was supported by Russian Foundation for Basic Research (grant 11-03-12160-ofi-m2011), Russian Academy of Sciences (Program of Division of chemistry and material science N 6 "Chemistry and physical chemistry of supramolecular systems and atomic clusters") and the Ministry of Education and Science of Russia, project 8433 .

\section{References}

1. The Porphyrin Handbook. Vol. 6. Applications: Past, Present and Future (Kadish K.M., Smith K., Guillard R., Eds.), San Diego: Academic Press, 2000.

2. Takai A., Chkounda M., Eggenspiller A., Gros C.P., Lachkar M., Barbe J.-M., Fukuzumi S. J. Am. Chem. Soc. 2010, 132, 4477-4489.

3. Takai A., Gros C.P., Barbe J.-M., Fukuzumi S. Chem. - Eur. J. 2011, 17, 3420-3428.

4. Takase M., Yoshida N., Nishinaga T., Iyoda M. Org. Lett. 2011, 13, 3896-3899.

5. Tong L.H., Pascu S.I., Jarrosson T., Sanders J.K.M. Chem. Commun. 2006, 1085-1087.

6. Xie Y., Akada M., Hill J. P., Ji Q., Charvet R., Ariga K. Chem. Commun. 2011, 47, 2285-2287.

7. Campbell W.M., Burrell A.K., Officer D.L., Jolley K.W. Coord. Chem. Rev. 2004, 248, 1363-1379.

8. Shinmori H., Kajiwara T., Osuka A. Tetrahedron Lett. 2001, 42, 3617-3620.

9. Beletskaya I.P., Tyurin V.S., Tsivadze A.Y., Guilard R., Stern C. Chem. Rev. 2009, 109, 1659-1713.

10. Drain C.M., Varotto A., Radivojevic I. Chem. Rev. 2009, 109, 1630-1658.

11. Chow H.-F., Lau K.-N., Ke Z., Liang Y., Lo C.-M. Chem. Commun. 2010, 46, 3437.

12. Li Y., Flood A.H. Angew. Chem. Int. Ed. 2008, 47, 2649

13. Juwarker H., Lenhardt J.M., Pham D.M., Craig S.L. Angew. Chem. Int. Ed. 2008, 47, 3740.

14. Séverac M., Le Pleux L., Scarpaci A., Blart E., Odobel F. Tetrahedron. Lett. 2007, 48, 6518-6522.

15. Shen D.-M., Liu C., Chen Q.-Y. Eur. J. Org. Chem. 2007, 1419-1422.

16. Shetti V.S., Ravikanth M. Eur. J. Org. Chem. 2010, 494-508.

17. HyperChem Release 8.0.9 for Windows, Hypercube, Inc., USA, (http://www.hyper.com), 2011.

18. Dilek D.K., Huma Z.S., Lindsey J.S. J. Org. Chem. 2007, 72, 7701-7714.

19. Benjamin L., Miller M.A., Lindsey J.S. J. Org. Chem. 1999, 64, 1391-1396.

20. Joydev L.K., Savithri D., Lindsey J.S. Org. Process Res. Dev. 2003, 7, 799-812. 
21. Uhl W., Bock H.R., Breher F., Claesener M., Haddadpour S., Jasper B., Hepp A. Organometallics 2007, 26, 2363-2369.

22. Benjamin L., Yangzhen C., Lindsey J. S. J. Org. Chem. 1999, 64, 2864.

23. Michael F.A., Lee O.P., Schuster D.I. Org. Lett. 2008, 10, 4979-4982.

24. Cecioni S., Sophie F., Vidal S., Chem. Eur. J. 2011, 17, 21462159;

25. Xien L., Jianhui L., Licheng S. Tetrahedron 2005, 61, 5655-5662.

26. Lindsey J.S., Brown P.A., Siesel D.A. Tetrahedron 1989, 45, 4845-4866.
27. Bock V.D., Hiemstra H., van Maarseveen J.H. Eur. J. Org. Chem. 2006, 51-68.

28. Kim Y.H., Jeong D.H., Osuka A. J. Am. Chem. Soc. 2001, 123, 76-86.

29. Cho H.S., Song N.W., Osuka A. J. Phys. Chem. A 2000, 104, 3287-3298.

30. Wook H., Atsuhiro O., Dongho K. J. Am. Chem. Soc. 2004, 126, 16187-16198.

31. Ballester P., Oliva A.I., Costa A., Deya P.M., Frontera A., Gomila R.M., Hunter C.A. J. Am. Chem. Soc. 2006, 128, 55605569.

Received 21.11.2012

Accepted 20.12.2012 